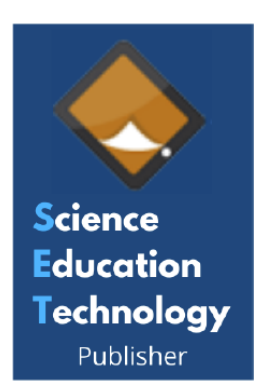

\title{
Mallotus Mollissimus and Solanum Erianthum Exhibit Antikinase, Antiphosphatase and Anti-Cancer Properties
}

\author{
Nurul Ain Ismail ${ }^{1}$, Azlinah Matawali ${ }^{2}$, Ping-Chin Lee ${ }^{1}$, Siew-Eng How ${ }^{1}$, Latifah Saiful Yazan ${ }^{3}$, \\ Lucky Poh Wah Goh ${ }^{1}$ and Jualang Azlan Gansau, ${ }^{1, *}$ \\ ${ }^{1}$ Faculty of Science and Natural Resources, Universiti Malaysia Sabah, Jalan UMS, 88400 Kota Kinabalu, Sabah, \\ Malaysia \\ ${ }^{2}$ Preparatory Centre for Science and Technology, Universiti Malaysia Sabah, Jalan UMS 88400 Kota Kinabalu, \\ Sabah, Malaysia \\ ${ }^{3}$ Department of Biomedical Science, Faculty of Medicine and Health Sciences, Universiti Putra Malaysia, 43400 \\ UPM, Serdang, Selangor, Malaysia
}

\section{Article Info:}

Keywords:

Cytotoxicity,

kinase,

Mallotus mollissimus,

phosphatase,

Solanum erianthum.

Timeline:

Received: September 02, 2021

Accepted: October 21, 2021

Published: November 04, 2021

Citation: Ismail NA, Matawali A, Lee PC, How S-E, Yazan LS, Goh LPW,

Gansau JA. Mallotus Mollissimus and Solanum Erianthum Exhibit Antikinase, Antiphosphatase and Anti-Cancer Properties. J Pharm Nutr Sci 2021; 11 : 93-100.

DOI: https://doi.org/10.29169/1927-5951.2021.11.12

${ }^{*}$ Corresponding Author

Tel: +60-88320000

E-mail: azlanajg@ums.edu.my

\begin{abstract}
:
Cancer is a leading cause of death worldwide and caused by dysregulated signal transduction from kinase and phosphatases. Inhibitors of kinase and phosphatase have demonstrated anticancer properties. Therefore, this study aimed to investigate the antikinase, antiphosphatase and cytotoxic properties of Mallotus mollissimus ( $M$. mollissimus) and Solanum erianthum (S. erianthum). Toxic activities against PP1, MKK1 and MSG5 assays were demonstrated by $S$. erianthum methanol extract. Bioassay-guided fractionation of the methanolic extracts showed that chloroform fraction (CE) of M. mollissimus exhibited toxic activity against PP1. Meanwhile, CE of $S$. erianthum showed positive activity on PP1 assay. Column chromatography separation of the CE has revealed that fractions $\mathrm{F} 1$ and $\mathrm{F} 2$ of $M$. mollissimus are toxic against PP1. Meanwhile, F1 and F2 CE fractions of $S$. erianthum were positive against PP1 and F9 fraction showed toxic activity in PP1 assay. Chloroform extracts of both plants exhibit cytotoxicity activity against HeLa, CaOV3 and MCF7 cell lines. This study demonstrated the potential of M. mollissimus and S. erianthum extracts in antikinase, antiphosphatase and anti-cancer activities which warrant further purification and identification.
\end{abstract}

(C) 2021 Ismail et al.; Licensee SET Publisher.

This is an open access article licensed under the terms of the Creative Commons Attribution Non-Commercial License (http://creativecommons.org/licenses/by-nc/3.0/) which permits unrestricted, non-commercial use, distribution and reproduction in any medium, provided the work is properly cited. 


\section{INTRODUCTION}

Cancer is a leading cause of death worldwide. It has been a global burden with the increasing number of cancer cases either in economically developed countries and developed countries [1]. There are approximately 18,219 cancer cases were reported in Malaysia [2]. The abnormality of signal transduction is one of the causes of cancer [3,4]. Signal transduction involves protein kinases and phosphatase carries out phosphorylation and dephosphorylation of protein, respectively [5-9]. Roughly $80 \%$ of renal cell carcinoma have high expression of MKK1 and ERK2 protein kinase [10]. Meanwhile, in DNA damage response protein phosphatase 1 acts as a negative regulator to inhibit the serine/threonine kinase phosphorylation process which causes cancer development and cellular growth [11].

Mallotus (Euphorbiaceae) and Solanum (Solanaceae) genera were used for a wide array of traditional medical applications. Leaves and stem bark of $M$. peltatus (Geist) Muell. Arg. var acuminatus was used to cure intestinal ailments, skin infections and trematodic infection [12]. Leaves of $M$. macrostachyus were used as an antidote against snake-poison [13]. Studies have demonstrated that several genera of Mallotus such as $M$. japonicus, $M$. peltatus, $M$. macrostachyus and $M$. phillipinesis exhibit strong antioxidant, antimicrobial and anti-inflammatory activities, antiproliferative effects against human breast cancer, wound healing and traditional treatments [12, 14-20].

The medicinal potential of Mallotus mollissimus which is indigenous to Malesia and Queensland, and Solanum erianthum which is indigenous to the tropical and sub-tropical America are poorly reported [21, 22]. Specifically, the antikinase and antiphosphatase activities of $M$. molissimus and S. erianthum. Hence, this study investigated the antikinase and antiphosphatase activities of $M$. mollissimus and $S$. erianthum extracts followed by anti-cancer study against cancer cell lines.

\section{MATERIALS AND METHODS}

\section{Plant Sample and Processing}

Leaves of Mallotus mollissimus ( $M$. mollissimus) and Solanum erianthum (S. erianthum) were collected from Kampung Seri Aman and Kampung Salimandut, Kota
Marudu, Sabah, respectively. The specimens were deposited at BORNEENSIS, Institute for Tropical Biology and Conservation (Voucher Specimen No. BORH 0969 and BORH 0971). M. mollissimus and S. erianthum leaves were dried and immersed in methanol $(1: 10 \mathrm{w} / \mathrm{v})$ for 72 hours. The concentrated methanolic extracts were further fractioned using liquidliquid extraction to yield chloroform (CE), chloroformmethanol (CME), and butanol (BE) fractions [23]. CE of $M$. mollissimus was then eluted using silica gel column chromatography with $0.040-0.063 \mathrm{~mm}$ and $230-400$ mesh with solvent system consists of hexane:ethyl acetate $(2: 1)(\mathrm{v} / \mathrm{v})$ to yield 13 pooled fractions (F1-F13). Meanwhile, $S$. erianthum was further separated by gradient elution with methanol: chloroform (3:17 v/v), methanol: chloroform $(7: 3 \mathrm{v} / \mathrm{v})$ and methanol $(99.9 \%$ $\mathrm{v} / \mathrm{v}$ ) yielding 10 pooled fractions (F1-F10).

\section{Microorganisms}

MAPK Kinase (MKK1), MAP Kinase Phosphatase (MSG5) and Protein Phosphatase 1 (PP1) yeast screening system were performed to determine the antikinase and antiphosphatase properties of plant extracts [24-26]. The yeast strains used were MKK1 ${ }^{\text {P386 }}$, MKK1 ${ }^{\text {P386 }}-$ MSG5, PAY704-1 (wild type) and PAY704-1 (mutant type) strains. There were kind gifts of Prof. Minoru Yoshida from University Tokyo, Japan and Prof. Michael J. Stark from the University of Dundee, Scotland.

\section{Antikinase $\left(\mathrm{MKK}^{\mathrm{p} 386}\right)$ Screening System}

The screening media consist of Part A and Part B were prepared separately [24, 27]. A final volume of $100 \mathrm{~mL}$ consists of Part A and Part B were mixed and $2 \mathrm{~mL}$ of yeast culture was added. Then, the media were poured into sterile Petri dishes and left to solidify. Sterile paper discs with a diameter of $6 \mathrm{~mm}$ were impregnated with $20 \mu \mathrm{L}$ of extracts $(100 \mathrm{mg} / \mathrm{mL})$. Discs were transferred onto the screening media. Each extract was tested on glucose and galactose plate and incubated at $28^{\circ} \mathrm{C}$ for 5 days. The test was done in triplicates. The diameter of inhibition zones $(\bar{x} \pm s \mathrm{~mm})$ in assays was recorded.

\section{Antiphosphatase (MKK1 ${ }^{\mathrm{P} 386}{ }_{\text {MSG5 }}$ AND PP1) Screening System}

The screening media for $M K K 1^{\mathrm{P} 386}$-MSG5 screening system consists of Part $A$ and Part $B$ were prepared separately $[24,28]$. Both $(100 \mathrm{~mL})$ Part $A$ and Part $B$ were mixed thoroughly and $2 \mathrm{~mL}$ of the yeast culture 
(dissolved in PBS buffer) was added into the screening medium. Then, media were poured into sterile Petri dishes and left to solidify. Sterile paper discs with $6 \mathrm{~mm}$ diameter were impregnated with $20 \mu \mathrm{L}$ of extracts $(100 \mathrm{mg} / \mathrm{ml})$. Discs were transferred onto the screening media. Each extract was tested on a glucose and galactose plate and incubated for 5 days at $28^{\circ} \mathrm{C}$. The test was done in triplicates.

PP1 screening assay uses two different types of media namely, YPD (Yeast Peptone Dextrose) and YPD+1M sorbitol media [26]. Screening media was mixed with $100 \mu \mathrm{l}$ of each yeast strain and poured into Petri dishes. Sterile paper discs (6 $\mathrm{mm}$ diameter) were impregnated with $20 \mu \mathrm{L}$ of extracts $(100 \mathrm{mg} / \mathrm{ml})$. The disc was transferred onto the screening media and incubated at $28^{\circ} \mathrm{C}, 37^{\circ} \mathrm{C}$ for 5 days. The screening test was done in triplicates. The diameter of inhibition zones $(\bar{x} \pm s \mathrm{~mm})$ in both screening systems were recorded.

\section{Cell Cytotoxic Assay}

Chloroform extracts (CE) of $M$. mollissimus and $S$. erianthum were screened for cytotoxic activity against Henrietta Lacks (HeLa), cellosaurus cell line (CaOV3) and Michigan Cancer Foundation-7 (MCF-7) cancer cell. Approximately, $1.0 \times 10^{5}$ of cells $/ \mathrm{mL}$ were treated with various concentrations $(\mu \mathrm{g} / \mathrm{mL})$ of $M$. mollissimus and $S$. erianthum chloroform extracts until cell death of $50 \%$ occurs. Next, the cells were subjected to centrifugation (450 $\mathrm{xg}$ for 10 mins) and washed twice with phosphate-buffered saline (PBS). Approximately, $20 \mu \mathrm{L} \quad$ of 3 -[4,5-dimethylthiazol-2-yl]2,5diphenyltetrazolium bromide (MTT) solution was added into the cell suspension and incubated at $37^{\circ} \mathrm{C}$, $5 \% \mathrm{CO}_{2}$ for 4 hours. The plate was spun at $450 \times \mathrm{xg}$ for 10 minutes and $50 \mu \mathrm{L}$ of media was aspirated. Subsequently, the formazan salt was dissolved by 100 $\mu \mathrm{L}$ of DMSO and left for 10 minutes at room temperature. The optical density (OD) was measured by using an ELISA reader (Sunrise, Tecan) at $570 \mathrm{~nm}$ test wavelength and $630 \mathrm{~nm}$ reference wavelength. The concentration that inhibits $50 \%$ of the cell growth compared to the untreated sample $\left(\mathrm{IC}_{50}\right)$ was determined by the absorbance (OD) versus concentration curve. The test was done in triplicates.

\section{RESULTS}

\section{Antikinase Activity}

The crude methanolic extracts of $M$. mollissimus did not exhibit any kind of activity as in MKK1 and MSG5
(Table 1). Whereas there is toxic activity shown by crude methanolic extracts of $S$. erianthum in MKK1 with growth in glucose plate $(7.50 \pm 0.71)$ and no growth in galactose plate. Moreover, MSG5 screening system indicated the crude methanol extracts also contains toxic activity as there were growth in glucose $(7.00 \pm 1.41)$ and galactose-containing $(10.0 \pm 0)$ plate.

Different fractions (chloroform fraction, chloroformmethanol fraction and butanol fraction) obtained from the liquid-liquid portioning $S$. erianthum were tested against MSG5 screening system observed that chloroform fraction did not have toxic activities up to 70 $\mathrm{mg} / \mathrm{ml}$, but there were inconsistent toxicities observed at $100 \mathrm{mg} / \mathrm{ml}$ at $9.50 \pm 0.58$ and $11.0 \pm 0$ in glucose and galactose plates, respectively (Table $\mathbf{S 1}$ ). Interestingly, the chloroform-methanol fraction of $S$, erianthum shows toxic activities against MKK1 and MSG5 from $10 \mathrm{mg} / \mathrm{ml}$ to $100 \mathrm{mg} / \mathrm{ml}$ (Table 2).

\section{Antiphosphatase Activity}

Crude methanolic extracts of $M$. mollissimus and $S$. erianthum demonstrated toxic activities in PP1 screening systems (Table 1). Bioassay-guided fractionation showed that the chloroform fractions shows toxic activity from $10 \mathrm{mg} / \mathrm{ml}$ to $100 \mathrm{mg} / \mathrm{ml}$ (Table S2). CE.F1 and CE.F2 also shows toxic activity at 10 $\mathrm{mg} / \mathrm{ml}$. S, erianthum shows highly potential activity in the chloroform fraction, CE.F1, CE.F2, CE.F9 and chloroform-methanol fraction (Table S2). The chloroform fraction exhibited as an inhibitor whereas chloroform-methanol fraction exhibited toxic activities from $10 \mathrm{mg} / \mathrm{ml}$ up till $100 \mathrm{mg} / \mathrm{ml}$. CE.F1 and CE.F2 fractions demonstrated Mpk1 activity at $10 \mathrm{mg} / \mathrm{ml}$.

\section{Cytotoxic Activities against 3T3, HeLa, CaOV3 and MCF-7 Cell Lines}

We observed that chloroform extracts of $M$. mollissimus and $S$. erianthum exhibit cytotoxic activities against HeLa, CaOV3 and MCF-7 cell lines ranges from $53.67 \pm 3.21 \mu \mathrm{g} / \mathrm{ml}-141.0 \pm 2.65 \mu \mathrm{g} / \mathrm{ml}$ of $\mathrm{IC}_{50}$ (Table 3 ). However, only chloroform extracts of $M$. mollissimus shows cytotoxic activities against 3T3 cell line of up to $98.83 \pm 3.55 \mu \mathrm{g} / \mathrm{ml}$ of $\mathrm{IC}_{50}$.

\section{DISCUSSION}

\section{Antikinase Activity}

MKK1 and MSG5 assays were performed to study the antikinase activity. MKK1 assay uses $M K K 1^{P 386}$ yeast strain that was able to grow on glucose medium but not on galactose. Hence, the growth of yeast can be 
compared between these two media. Yeast cells have a stunted growth through overexpression of MKK $1^{\mathrm{P} 386}$ when promoted by a strong GAL1 promoter. 


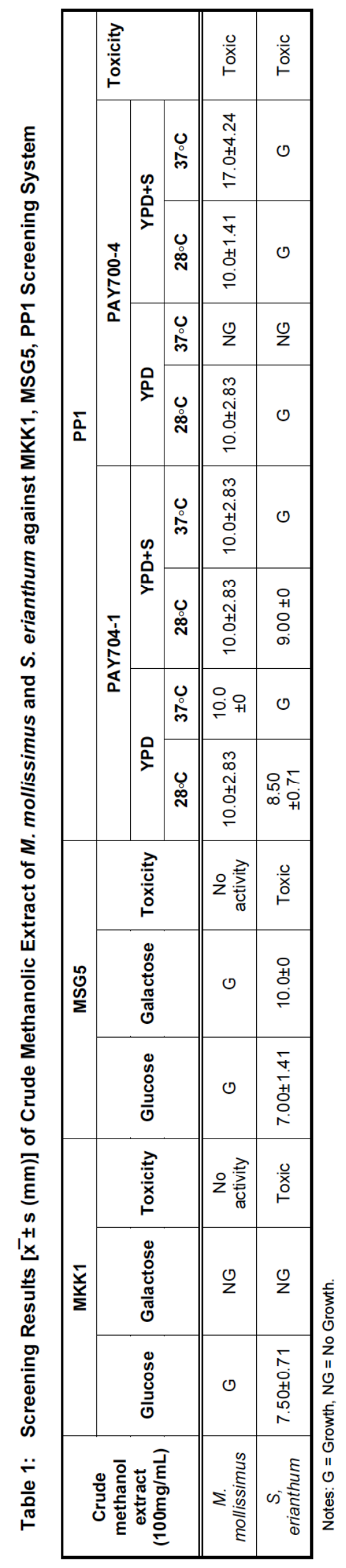

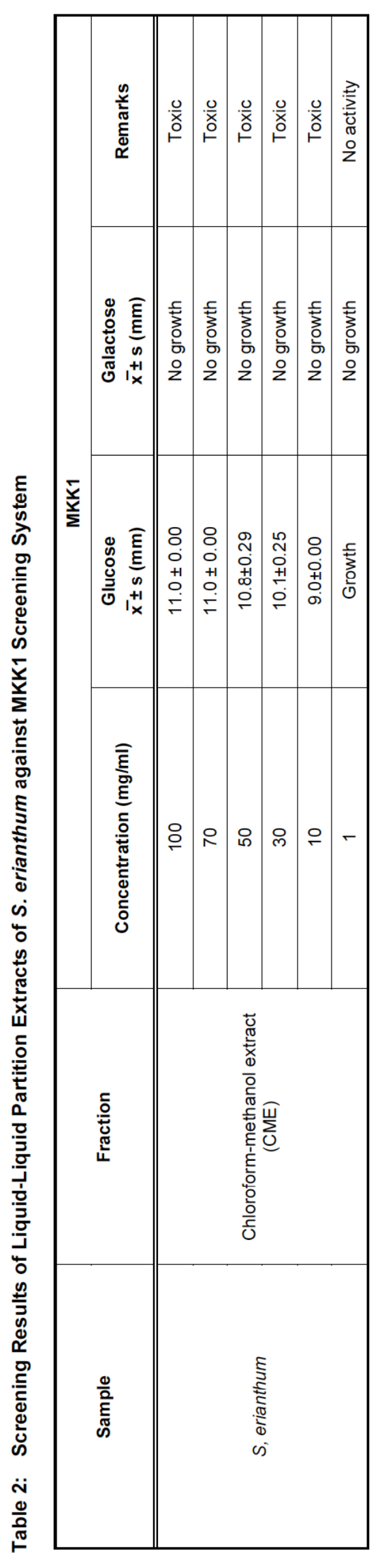

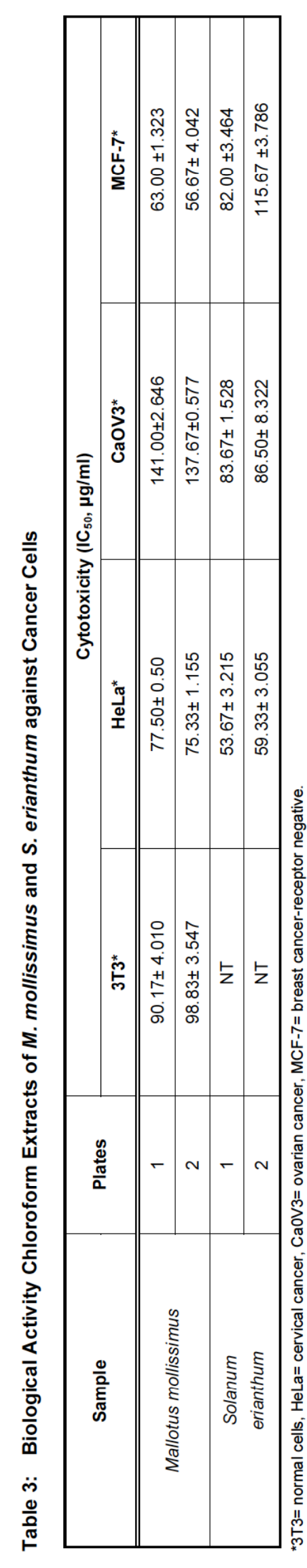


The presence of galactose induced the GAL1 promoter which resulted in the overexpression of MKK $1^{\mathrm{P} 386}$ that inhibit the growth of yeast cells. Hence, the presence of potential inhibitor that inhibits $\mathrm{MKK} 1^{\mathrm{P} 386}$ causes cell growth due to the inhibition of Pkc pathway at Bck1, MKK1 or Mpk1 [24]. MSG5 screening assay was conducted to specify the targets of MKK1 activities ${ }^{22}$. Results showed only $S$. erianthum extract exhibit toxicity against MKK1 screening system and no activity for M. mollissimus extract (Table 1). Subsequent liquidliquid separation revealed CME fraction of $S$. erianthum contains toxic activity where an inhibition zone was observed in the glucose plate for MKK1 assay (Table 2). This fraction exhibits a toxic effect to a low as 10 $\mathrm{mg} / \mathrm{ml}$ of concentration.

\section{Antiphosphatase Activity}

MSG5 inhibitor screening uses a mutant yeast $\left(M K K 1^{P 3386}\right)$ that carries MSG5 plasmid producing MKK1 ${ }^{\text {P386 }}$ MSG5 yeast strain. MSG5 is a protein phosphatase and its substrates are MAP kinase, family members. Overexpression of MSG5 suppresses the toxic effect caused by hyperactivation of the Mpk1 pathway by dephosphorylating and inactivating Mpk1 MAPK. Hence, the uninduced GAL1 promoter causes the mutant yeast to grow on a glucose medium. However, yeast strain could also grow on galactose plate because of the overexpression of MSG5 will inhibit Mpk1 which consequently suppresses the growth inhibition due to overexpression of $M K K 1^{\mathrm{P} 386}$ $[24,28]$. If the inhibitory activities of the extract on both MKK1 and MSG5 assay, thus it can be interpreted that the inhibition of specific on MKK1. Results in Table 1 shows that only crude methanolic extract of $S$. erianthum has a toxic effect against MSG5 screening system.

Further separation shows only CME fraction exhibit stable toxic activity with inhibition zone in both glucose and galactose plates for MSG5 assay at as lower as 10 $\mathrm{mg} / \mathrm{ml}$ concentration. Meanwhile, CE and BE fractions promoted inconsistent toxic activity against MSG5 assay (Table $\mathbf{S 1}$ ).

Antiphosphatase activity was performed using PP1 screening assay targeting type-1 protein serine/threonine phosphatase (PP1). GLC7 in Saccharomyces cerevisiae encodes the catalytic subunit of type I protein serine/threonine phosphatase (PP1). Saccharomyces cerevisiae with temperaturesensitive $g / c 7$ allele $(g / c 7-10)$ which exhibits a $G_{2} / M$ arrest at the restrictive temperature. This gene causes kinetochore functions to defect at $37^{\circ} \mathrm{C}$. Microtubulebinding activity decreases in the presence of ATP presence at both $37^{\circ} \mathrm{C}$ and $26^{\circ} \mathrm{C}$. Depletion of ATP by apyrase restored the microtubule-binding activity in wild type strain. However, this activity was not restored in g/c7-10 at $37^{\circ} \mathrm{C}$ extracts and marginally restored in glc7-10 at $26^{\circ} \mathrm{C}[26,29]$. At restrictive temperature, the activities of PP1 mutant (g/c7-10) were able to be mimic by a potential inhibitor. g/c7-10 causes cell cycle arrest and impairment of cell wall integrity at $37^{\circ} \mathrm{C}$, but cellular growth and membrane integrity are rescued by adding $1 \mathrm{M}$ of sorbitol. Therefore, a potential inhibitor that acts on wild-type GLC7 should demonstrate similar properties with the rescue of cell proliferation and membrane integrity by $1 \mathrm{M}$ of sorbitol. Hence, no inhibition zone at the wild type strain with $1 \mathrm{M}$ of sorbitol $[26,29]$. PP1 assay shows that crude methanolic extracts of both tested species exhibit toxicity (Table 1 ).

Further tests on methanol fractions of both species have resulted that only CE of $M$. mollissimus $S$ promote potential inhibitory against PP1 assay at as low as $10 \mathrm{mg} / \mathrm{ml}$ concentration (Table S2). The inhibitory activity of CE fraction is due to the ability to inhibit a normal but reversible GLC7 which could be rescued by sorbitol that would not affect mutant PAY700-4 which carries g/c7-10 allele [26]. This is shown by the inhibition growth of PAY704-1 which is only at YPD medium $37^{\circ} \mathrm{C}$. CE fraction of $M$. mollissimus and $\mathrm{CME}$ fraction of $S$. erianthum exhibit toxicity. No activity was observed for $\mathrm{CME}$ and $\mathrm{BE}$ fractions for $M$. mollissimus and $\mathrm{BE}$ fraction of $S$. erianthum in PP1 assay, respectively.

CE fractions of $M$. mollissimus and $S$. erianthum were subjected to further column chromatography fractionation and later tested against PP1 screening system (Table S2). We observed that CE.F1 and CE.F2 of M. mollissimus were toxic to PP1 due to the presence of inhibition zones on both yeast PAY704-1 and PAY700-4 at $27^{\circ} \mathrm{C}$. In contrast with that, fraction 1 (CE.F1) and fraction 2 (CE.F2) of S. erianthum showed potential activities as inhibitor for Mpk1 cascade. The inhibition zone was detected for PAY704-1 growth on YPDS at $37^{\circ} \mathrm{C}$. Meanwhile, Fraction 9 (CE.F9) showed toxic activity. Other fractions did not show any activity (data not shown).

\section{Cytotoxic Assay}

Cytotoxicity of $M$. mollissimus and $S$. erianthum chloroform extract against HeLa, CaOV3 and MCF-7 cells were evaluated (Table 3 ). Extracts of $M$. 
mollissimus were moderately toxic against HeLa (77.50 $\mu \mathrm{g} / \mathrm{ml} \pm 0.50)$ and MCF-7 $(63.00 \mu \mathrm{g} / \mathrm{ml} \pm 1.323)$ and exhibited weak activity with the $\mathrm{IC}_{50}$ values of 141.00 $\mu \mathrm{g} / \mathrm{ml} \pm 2.646$ against CaOV3 cells. Meanwhile, $S$. erianthum, extract showed moderate activity against Hela, CaOV3 and MCF-7 with $\mathrm{IC}_{50}$ of $53.67 \mu \mathrm{g} / \mathrm{ml} \pm$ $3.215,83.67 \mu \mathrm{g} / \mathrm{ml} \pm 1.528$, and $82.00 \mu \mathrm{g} / \mathrm{ml} \pm 3.464$, respectively. This shows that extracts of $M$. mollissimus and $S$. erianthum were able to exhibit anticancer activity.

\section{CONCLUSION}

This study demonstrated activities of $S$. erianthum in PP1 assay, whereas toxic activities were observed in MSG5 and MKK1 assays. M. mollissimus only showed toxic activities for antiphosphatase assays. Cytotoxicity test showed that both plants extracts showed potential anticancer activities. These findings highlighted the potential of $S$. erianthum and $M$. mollissimus extracts which indicated subsequent characterization and elucidation of the active constituent(s) could serve as antikinase, antiphosphatase and anticancer agents.

\section{ACKNOWLEDGEMENTS}

The authors would like to thank Prof. Michael J. Stark from University of Dundee, Scotland and Prof. Minoru Yoshida from University Tokyo, Japan for providing the yeast strains. This work was funded by the Malaysia Ministry of Science, Technology, and Innovation (Science Fund 02-01-10-SF0107).

\section{CONFLICT OF INTERESTS}

The authors declare that there is no conflict of interest.

\section{SUPPLEMENTAL DATA}

The supplemental data can be downloaded from the journal website along with the article.

\section{REFERENCES}

[1] Ahmedin J, Bray F, Center MM, Ferlay J, Ward E, Forman D. Global Cancer Statistics. CA Cancer: J Clin 2011; 61: 69-90. https://doi.org/10.3322/caac.20107

[2] National Cancer Registry (NCR), Malaysia, National cancer registry report: Malaysia cancer statistics-data and figure 2007, Ministry of Health, Malaysia 2007.

[3] Biok J. Natural Compounds in cancer therapy, $1^{\text {st }}$ ed. Oregon Medical Press, LLC 2001.

[4] Seger R, Krebs EG. The MAPK signaling cascade. FASEB J 1995; 9: 726-735. https://doi.org/10.1096/fasebj.9.9.7601337

[5] Robinson MJ, Cobb MH. Mitogen-activated protein kinase pathway. Curr Opin Cell Biol 1997; 9: 180-186. https://doi.org/10.1016/S0955-0674(97)80061-0
[6] Shenolikar S. Protein Serine/Threonine Phoshatase - New Avenues for Cell Regulation. Ann Rev Cell Biol 1994; 10: 5586.

https://doi.org/10.1146/annurev.cb.10.110194.000415

[7] Hunter T. Protein Kinase and Phosphatase: The Yin and Yang of Protein Phosphorylation and Signaling. Cell 1995; 80: 225-236.

https://doi.org/10.1016/0092-8674(95)90405-0

[8] Keyse SM. Protein phosphatase and the regulation of mitogen-activated protein kinase signaling. Curr Opin Cell Biol 2000; 12: 186-192. https://doi.org/10.1016/S0955-0674(99)00075-7

[9] Krauss G. Biochemistry of Signal Transduction and Regulation. 3rd ed. Weinheim: Wiley-VCH 2003. https://doi.org/10.1002/3527601864

[10] Huang D, Ding Y, Luo WM, Bender S, Qian CN, Kort E, Zhang ZF, VandenBeldt K, Duesbery NS, Resau JH. The Inhibition of MAPK kinase signaling pathways suppressed renal cell carcinoma growth and angiogenesis in vivo. Cancer Res 2008; 68: 81-88. https://doi.org/10.1158/0008-5472.CAN-07-5311

[11] Peng A, Maller JL. Serine/threonine phosphatase in the DNA damage response and cancer. Oncogene 2010; 29: 59775988.

https://doi.org/10.1038/onc.2010.371

[12] Chattopadhyay D, Arunachalam G, Mandal AB, Sur TK Mandal SC, Bhattacharya SK. Antimicrobial and antiinflammatory activity of folklore: Mallotus peltatus leaf extract. J Ethnopharmacol 2002; 82: 229-237. https://doi.org/10.1016/S0378-8741(02)00165-4

[13] Sierra SEC, Van Welzen PC. A taxonomic revision of Mallotus section Mallotus (Euphospbiaceae) in Malesia, Blumea. J Plant Taxon Plant Geo 2005; 50: 249-274. https://doi.org/10.3767/000651905X622987

[14] Arunachalam G, Paromita B, Chattopadhyay D. Phytochemical and phytotherapeutic evaluation of Mallotus peltatus (Geist.) Muell. Arg. var acuminatus and Alstonia macrophylla wall ex A. DC: Two ethno medicine of Andaman Islands, India. J Pharmacognosy Phytotherapy 2009; 1: 001013.

[15] Nurhanan MY, Asiah O, Mohd Ilham MA, Siti Syarifah MM, Norhayati I, Lili Sahira H. Anti-proliferative activities of 32 Malaysia plant species in breast cancer cell lines. J Trop Forest Sci 2008; 20: 77-81.

[16] Tabata H, Katube T, Tsuma T, Ohta $\mathrm{Y}$, Imawaka N, Utsum $\mathrm{T}$. Isolation and evaluation of the radical-scavenging activity of the antioxidants in the leaves of an edible plant, Mallotus japonicus. Food Chem 2008; 109: 64-71. https://doi.org/10.1016/j.foodchem.2007.12.017

[17] Blomqvist MM, Nguyen T. Solanum erianthum $D$. Don[Internet] Record from Proseabase. de Padua L.S., Bunyapraphatsara N. and Lemmens R.H.M.J. (Editors). PROSEA (Plant Resources of South-East Asia) Foundation, Bogor, Indonesia. 1999. http://www.proseanet.org. Accessed from Internet: 19-Feb-2020

[18] Ignacimuthu S, Ayyanar M, Sankara Sivaraman K. Ethnobotanical investigations among tribes in Madura District of Tamil nadu (India). J Ethnobiol Ethnomed 2006; 2: 25. https://doi.org/10.1186/1746-4269-2-25

[19] Muhammad Shaiq A, Shahnaz ST, Isiaka AO, Muhammad $\mathrm{KP}$, Oladosu Al. Naturally Occurring Antifungal Aromatic Esters and Amides. J Chem Soc Pakistan 2010; 32: 565570.

[20] Ibikunle GF. Pharmacological effects of leaves and fruits of Solanum erianthum (Solanaceae) for anti-trichomona activity. Int J Life Sci Pharma Res 2012; 2: L185-190.

[21] Zich FA, Hyland, Whiffen T, Kerrigan RA. "Mallotus mollissimus". Australian Tropical Rainforest Plants Edition 8 
(RFK8). Centre for Australian National Biodiversity Research (CANBR), Australian Government. https://apps.lucidcentral.org/rainforest/text/entities/mallotus_ mollissimus.htm. Accessed from Internet: 7-Oct-2021.

[22] Germplasm resources information network. Agricultural research service, United States Department of Agriculture. https://npgsweb.ars-

grin.gov/gringlobal/taxon/taxonomydetail?id=313893 Accessed from Internet: 7-Oct-2021.

[23] Harborne JB. Phytochemical Methods-A Guide to Modern Techniques of Plant Analysis. $3^{\text {rd }}$ Ed. Chapman and Hall, London 1998.

[24] Watanabe Y, Irie K, Matsumoto K. Yeast RLM1 encodes a serum response factor-like protein that may function downstream of the Mpk1 (Sit2) mitogen-activated protein kinase pathway. Mol Cell Biol 1995; 15: 5740-5749. https://doi.org/10.1128/MCB.15.10.5740

[25] Ho CC. Molecular Cell Biology, Biodiversity and Biotechnology. $1^{\text {st }}$ ed. Percetakan CCS Sdn Bhd, Malaysia 2003.
[26] Andrews PD, Stark MJR. Type 1 protein phosphatase is required for maintenance of cell wall integrity, morphogenesis and cell cycle progression in Saccharomyces cerevisiae. J Cell Sci 2000; 113: 507-520.

https://doi.org/10.1242/jcs.113.3.507

[27] Gustin MC, Albertyn J, Alexander M, Davenport K. MAP Kinase pathways in Yeast Saccharomyces cerevisiae. Microbiol Mol Biol Rev 1998; 62: 1264-1300. https://doi.org/10.1128/MMBR.62.4.1264-1300.1998

[28] Doi K, Gartner A, Ammerer G, Errede B, Shinkawa H, Sugimoto K, Matsumoto K. Msg5, a novel protein phosphatase promotes adaptation to pheromone in $\mathrm{S}$. Cerevisiae. EMBO J 1994; 16: 61-70. https://doi.org/10.1002/j.1460-2075.1994.tb06235.x

[29] Sasoon I, Severin FF, Andrews PD, Taba M, Kaplan KB, Ashford AJ, Stark MJR, Sorger PK, Hyman AA. Regulation of Saccharomyces cerevisiae kinetochores by the type 1 phosphatase Glc7p. Genes Devel 1995; 13: 545-555. https://doi.org/10.1101/gad.13.5.545 